\title{
Środowisko wychowawcze rodziny Hanny Chrzanowskiej
}

Nie wolno zapominać o tym prostym fakcie, że norma etyczna człowieka jest jego sumienie ${ }^{1}$.

Rodzina w dziejach każdego społeczeństwa decyduje o żywotności zarówno tradycji rodzinnych, społecznych, jak i narodowych ${ }^{2}$. Człowiek jako istota społeczna, by się rozwijać, potrzebuje drugiego człowieka. Potrzeba ta jest szczególnie wyraźna w sytuacji, gdy zabraknie rodziny. W sposób szczególny osoba potrzebuje obecności i pomocy w dzieciństwie, w chorobie i osamotnieniu, w biedzie i niedoli. Czasem na drodze życia spotyka jednak dobrego samarytanina.

Hanna Chrzanowska, herbu Korab, przyszła na świat 7 października 1902 roku, w bardzo zamożnej rodzinie. Był to czas, kiedy na świecie nie brakowało chorych, a wielu samotnych pozostawało w izolacji i zapomnie-

\footnotetext{
${ }^{1}$ H. Chrzanowska, Pamiętniki, listy, notatki, Kraków 2018, s. 21.

${ }^{2}$ Zob. np.: Wychowanie w rodzinie: od starożytności po wiek XX, red. J. Jundziłł, Bydgoszcz 1994; Rodzina jako środowisko wychowawcze w czasach nowożytnych, red. K. Jakubiak, Bydgoszcz 1995; Źródła do dziejów wychowania w rodzinie polskiej w XIX i początkach XX wieku, wybór i oprac. A. Denisiuk, K. Jakubiak, Bydgoszcz 2001.
} 
niu. W ciągu życia służyła ojczyźnie. Dziś jest zasłużona dla nauki, kultury i pielęgniarstwa polskiego.

Wychowanie człowieka odbywa się w określonej rodzinie. To tu kształtują się jego poglądy, wiara i system wartości, a także normy postępowania. „W kręgu rodzinno-domowym [Hanny] skupiały się wszystkie zjawiska kulturowe, cywilizacyjne, mentalnościowe, obyczajowe i polityczne"3. Ta panienka $\mathrm{z}$ domu pełnego przepychu i miłości $\mathrm{w}$ dorosłym życiu podjęła niezwykłe działania na rzecz najsłabszej części społeczeństwa, co postawę taką wyniosła od rodziców. .

Hanna, pielęgniarka, działaczka charytatywna, pisarka, pedagog, instruktorka i prekursorka pielęgniarstwa rodzinnego, domowego i parafialnego, pełniła równocześnie funkcje wiceprzewodniczącej oraz była członkiem Zarządu Głównego Polskiego Stowarzyszenia Pielęgniarek Zawodowych, a także naczelną redaktor czasopisma „Pielęgniarka Polska”. Troszczyła się nie tylko o ciało chorych, ale i o ich życie duchowe. To dlatego współorganizowała dla nich rekolekcje.

Kiedy Hanna Chrzanowska przyszła na świat, Polski nie było na mapie Europy - w wyniku rozbiorów jej ziemie zostały podzielone między Austrię, Prusy i Rosję. W pamiętnym 1902 roku wiele działo się na arenie politycznej. W zaborze pruskim miał miejsce strajk uczniów we Wrześni protestujących przeciwko nauce religii w języku niemieckim. W Królestwie Polskim w czasie rewolucji 1905-1906 żądano wprowadzenia polskiego języka nauczania. W Warszawie otworzono pierwszy szpital żydowski. W „Tygodniku Ilustrowanym" w 1902 roku wydrukowano pierwszy fragment Chłopów W.S. Reymonta.

Pomimo dynamiki zdarzeń i niespokojnego czasu dom rodzinny zapewniał Hannie poczucie bezpieczeństwa i przekazał wrażliwość na potrzeby innych. Jak sama pisze: „Wzrastałam w atmosferze pomocy drugim i tzw. wówczas dobroczynności jako w najnaturalniejszej aurze"4. Trzeba dodać, że rodzina, jako środowisko wychowawcze, była i jest nadal stosunkowo mało podatna na zmiany i innowacje wychowawcze. Raczej, zarówno w przeszłości, jak i obecnie, kontynuuje tradycyjne sposoby wychowania.

\footnotetext{
${ }^{3}$ D. Kałwa, Polska doby rozbiorów i międzywojenna, w: Obyczaje w Polsce. Od średniowiecza do czasów współczesnych, red. A. Chwalba, Warszawa 2008, s. 242.

${ }^{4}$ H. Chrzanowska, Pamiętniki...
} 


\section{Rodzina Hanny Chrzanowskiej}

Rodzina Chrzanowskich, zasłużona w powstaniu styczniowym, cieszyła się uznaniem i szacunkiem. Słynęła z filantropii i wspierania potrzebujących. Ojciec - Ignacy Chrzanowski ${ }^{5}$ - pochodził z rodziny ziemiańskiej z Podlasia. Przez matkę Helenę z Dmowskich był spokrewniony z Joachimem Lelewelem i Henrykiem Sienkiewiczem, był ciotecznym siostrzeńcem Henryka Sienkiewicza. Profesor Ignacy Chrzanowski prowadził badania nad literaturą staropolską, a jego podręcznik akademicki Historia literatury niepodległej Polski kształtował stosunek wielu pokoleń do dawnego piśmiennictwa (od 1908 roku książka miała kilkanaście wydań).

W rodzinie Ignacego Chrzanowskiego szczególnie mocne było przywiązanie do tradycji patriotycznych. Pradziadek Hanny - Ignacy Kajetan Chrzanowski ${ }^{6}$ - był współzałożycielem tajnego Bractwa Burszów Polskich na Uniwersytecie Warszawskim. Wszystkich z pięciorga rodzeństwa dziadka Hanny, Bolesława, dotknęły represje związane z udziałem w spisku w 1848 roku, zakończone zesłaniem i emigracją. Dziadek Bolesław Chrzanowski, jako najmłodszy z rodzeństwa, uczestniczył w powstaniu styczniowym. Za udział w zrywie powstańczym, po jego stłumieniu, został uwięziony w Cytadeli Warszawskiej, gdzie zakończył żywot.

Matka Hanny, Wanda ze Szlenkierów, pochodziła z ewangelicko-augsburskiej rodziny zamożnych przemysłowców ${ }^{7}$. Pałac Szlenkierów z wiel-

\footnotetext{
${ }^{5}$ Ignacy Chrzanowski, po ukończeniu gimnazjum warszawskiego, studiował filologię, filozofię i historię na Uniwersytecie Warszawskim i Wrocławskim, uzupełniał studia w Berlinie i Paryżu, a od 1894 roku pracował jako nauczyciel historii literatury, historii Polski i języka polskiego w szkołach prywatnych w Warszawie. W 1910 roku został zatrudniony na Uniwersytecie Jagiellońskim.

${ }^{6}$ Chrzanowscy byli rodziną ziemiańską. Dziadek Ignacego Chrzanowskiego (18011869), a pradziadek Hanny, Kajetan Chrzanowski, był absolwentem Uniwersytetu Warszawskiego, w późniejszym okresie urzędnikiem Komisji Skarbu w Warszawie, pedagogiem i literatem. W 1829 roku założył i wydawał „Tygodnik dla Dzieci”, a rok później ze Stanisławem Jachowiczem, wydał „Dziennik dla dzieci”. Z małżeństwa z Joanną Zembrzuską urodziło się 5 dzieci: Adolf, Zdzisław, Ludmiła, Wanda i Bolesław (1831-1917) - ojciec Ignacego Chrzanowskiego, który do roku 1869 był właścicielem Stoku, a następnie kupił majątek Dziadkowskie, na którym gospodarował do objęcia prezesury Dyrekcji Towarzystwa Kredytowego Ziemi Siedleckiej.

${ }^{7}$ Dziadkowie ze strony matki byli od pokoleń garbarzami. Karol Jan Szlenkier, dziadek Hanny, w wieku kilkunastu lat stracił ojca, po którym odziedziczył garbarnię, którą rozbudował na rogu ulic Leszno i Żelaznej w Warszawie, otworzył filę fabryki w Berdyczowie. Założył tam ogromne ogrody, sprowadzał z Holandii i Belgii cebulki kwiatowe, krzewy i drzewka
} 
ką starannością i przepychem wybudowany dla rodziny Chrzanowskich w centrum Warszawy (przy ul. Senatorskiej 38) ${ }^{8}$, od roku 1922 stał się siedzibą włoskiej misji dyplomatycznej, obecnie mieści się w nim Ambasada Republiki Włoskiej.

Obie rodziny - Szlenkierów i Chrzanowskich - znane były z patriotyzmu i wielu dzieł dobroczynnych. W pamiętniku Hanna tak pisała o światopoglądzie swoich rodziców: „Oboje byli niewierzący: i moja matka (w paszporcie wyznania ewangelicko-augsburskiego), długie lata w mękach ateistycznego pesymizmu, i mój ojciec (w paszporcie rzymski katolik) pozytywistyczny wówczas liberał co się zowie! Ale każde z nich straciło inną wiarę i każdemu z nich został po niej inny osad”. "Nigdy nie słyszałam - ja, która wyrosła w atmosferze dobroczynności, że się ją pełni dla miłości Boga i z miłości do Boga. Tkliwość macierzyńska, którą otaczała mnie jak skrzydło pisklę, była obok całej swojej miękkości, najeżona twardymi nakazami obowiązku i zatroskania, czy sprostam, czy nie zdradzę linii?"”10.

Szczególna więź łączyła Hannę z ojcem, który zaszczepił w niej humanistyczną wrażliwość i miłość do literatury. Nikogo nie dziwiło zatem, że później wybrała studia polonistyczne. „Z miłości ojcowskiej (tak niezmiernej do końca życia) do mnie tryskał optymizm, krzepiąca wyrozumiałość na słabości mojej natury. Chociaż i ojciec nie kazał mi być dobrą dla Boga i przez Boga, chociaż i on był fanatykiem obowiązku, przede wszystkim patriotycznego, nie miał ze mną rozmów zasadniczych, od których dostaje się gęsiej skórki”"11.

W wychowanie Hanny bardzo zaangażowana była babka Maria Szlenkierowa, z domu Grosser. Siostra matki - Zofia Szlenkierówna - swój rodzinny spadek w 1913 roku ofiarowała na budowę w Warszawie, przy ulicy

ozdobne. Jako pierwszy w kraju sprowadzał skóry z krów indyjskich, jeździł do Chin i Indii, założył w Warszawie fabrykę firanek, tiulu i koronek. Stał się jednym z najbardziej przedsiębiorczych i najzamożniejszych obywateli stolicy. Po jego śmierci trzy córki: Maria, Wanda (matka Hanny) i Zofia, a także syn Karol Stanisław, odziedziczyli majątek wartości ok. 6 milionów rubli (wówczas 2 ruble równały się jednemu dolarowi). Zgodnie z wolą zmarłego pół miliona rubli przeznaczonych było od razu na cele charytatywne i społeczne, znaczne sumy zostały wydane także na podobne cele przez spadkobierców.

${ }^{8}$ Fundator pałacu, dziadek Hanny ze strony matki, znany warszawski garbarz, ale i mecenas sztuki, wznosił go w latach 1881-1883 na wzór renesansowego pałacu włoskiego wg projektu architekta Witolda Lanciego, a wnętrza ozdabiał m.in. Wojciech Gerson.

${ }^{9}$ H. Chrzanowska, Pamiętniki..., s. 28.

${ }^{10}$ Tamże.

${ }^{11}$ Tamże. 
Żytniej 39, szpitala dziecięcego (dziewięć pawilonów), do dziś ocalał tylko jeden (w 1989 roku na budynku umieszczono tablicę upamiętniającą fundatorkę). Szpital ten odegrał znaczącą rolę w życiu małej Hani. Jako 10-letnia dziewczynka, kiedy zachorowała na czerwonkę, znalazła w nim troskliwą i serdeczną opiekę - i być może właśnie to miało wpływ na kształtowanie jej zainteresowań i pasji.

Zofia Szlenkierówna (ciotka Hanny) studiowała na Wydziale Lekarskim w Genewie, a później w londyńskiej Szkole Pielęgniarskiej, słynnej Florence Nighingale, prekursorki nowoczesnego pielęgniarstwa światowego. Miała już wówczas w planach wybudowanie nowoczesnego szpitala dla dzieci w Warszawie (poświęciła na ten cel majątek otrzymany po rodzicach). Założony przez nią szpital Karola i Marii okazał się najnowocześniejszym w Europie (oddany do użytku w 1913 roku). Dla Hanny Zofia Szlenkierówna była wzorem, który będzie przyświecał jej osobistemu powołaniu zawodowemu.

\section{Okres krakowski - przed wybuchem Wielkiej Wojny}

W 1910 roku rodzina Chrzanowskich przeniosła się z Warszawy do Krakowa, ponieważ Ignacy Chrzanowski został zatrudniony jako profesor Uniwersytetu Jagiellońskiego i kierownik Katedry Historii Literatury Polskiej. O nominacji profesora zadecydowała opinia Stanisława Tarnowskiego, który wysoko ocenił podręcznik Chrzanowskiego Historia literatury niepodległej Polski (1906). Uczniami profesora byli poloniści tej miary, co Julian Krzyżanowski, Stanisław Pigoń, Kazimierz Wyka. We wspomnieniach profesorów jawi jako polski szlachcic w najlepszym tego słowa znaczeniu. Był nim w stylu swojego życia: w wytwornych manierach, w kulturalnej atmosferze gościnnego domu, $w$ temperamencie pisarza.

Rok 1910 obfitował w znamienne wydarzenia. W różnych miejscach na świecie pojawiały się inicjatywy socjalistyczne, szereg krajów dążyło do niepodległości, trwały utarczki na tle narodowościowym, ogłoszono 8 marca Dniem Kobiet. Feliks Nowowiejski skomponował muzykę do Roty Marii Konopnickiej. W lipcu trwały uroczyste obchody rocznicy bitwy pod Grunwaldem. Po zlocie grunwaldzkim zaczęto tworzyć, za zgodą władz austriackich, polowe Drużyny Sokole (wojskowe) i skauting. 
Szczęśliwe lata Hanna spędzała na domowej nauce, okresowych wyjazdach z babcią Szlenkierową do południowej Francji, na sanatoryjnych kuracjach w Zakopanem. Uchodziła za chorowite dziecko. Po przenosinach Chrzanowskich do Krakowa Hania zmieniła szkołę: w latach 1911-1912 uczęszczała na pensję panny Stanisławy Okołowiczówny ${ }^{12}$.

Lata 1910-1914 zapisały się w historii nie tylko rodziny Chrzanowskich, ale przede wszystkim na świecie. Rozpoczyna się rewolucja meksykańska. W 1912 roku zatonął Titanic. Była to największa tego rodzaju katastrofa statku pasażerskiego. 28 czerwca 1914 roku w wyniku zamachu na austriackiego następcę tronu arcyksięcia Franciszka Ferdynanda Habsburga wybuchła I wojna światowa - największy konflikt zbrojny w Europie od czasu wojen napoleońskich.

\section{Wojenne lata 1914-1918}

Wielka Wojna, jak określana jest dziś I wojna światowa, zakończyła się klęską państw centralnych, likwidacją mocarstw oraz powstaniem licznych państw narodowych. Była też jedną z głównych przyczyn rewolucji lutowej i rewolucji październikowej w Rosji. Powstało ZSRR. W czasie walk zginęło ponad 14 milionów ludzi: cywilów i żołnierzy. Zmienił się istniejący dotychczas świat. Wojna wyznaczyła symboliczne zakończenie wieku XIX oraz koniec hegemonii europejskiej na świecie.

\section{Wydarzenia lat 1918-1920}

Dnia 17 lipca 1918 roku miała miejsce egzekucja, dokonana przez władze bolszewickie, carskiej rodziny Romanowów. Nastąpił też rozpad Austro-Węgier. W wyniku wielu wydarzeń, jakie miały miejsce w tym czasie w Europie, Polska 11 listopada 1918 roku odzyskała utraconą niepodle-

\footnotetext{
${ }^{12}$ Stanisława Okołowiczówna, wcześniej prowadziła prywatne komplety w domu Wacława Sieroszewskiego w Zakopanem, a następnie - w zwiększonym składzie - w wilii Chowanna. Po 1911 roku przeniosła się do Krakowa i założyła na ul. Pańskiej (obecnie Marii Curie-Skłodowskiej) jedną z lepszych prywatnych szkół stopnia podstawowego. Wśród nauczycieli był m.in. Marian Falski, późniejszy autor Elementarza dla dzieci i reformator szkolnictwa w okresie międzywojennym.
} 
głość. Marzenie pięciu pokoleń stało się faktem. W kraju szybko podjęto starania zbudowania jednolitego i spójnego państwa. W wyniszczonym wojną społeczeństwie było wielu głodnych i niedożywionych, brakowało też środków na odbudowę wolnej ojczyzny.

Pomimo odzyskanej niepodległości były to trudne i burzliwe lata dla Polski i dla Europy: w 1920 roku epidemia grypy, tzw. hiszpanki, zabiła 20 milionów ludzi, w tymże roku Rosja bolszewicka zaatakowała Polskę i wybuchła wojna polsko-bolszewicka. Zwycięska obrona Warszawy przeszła do historii jako Cud nad Wisłą. Była też uważana za 18 przełomową bitwą w dziejach świata, bowiem zadecydowała o zachowaniu niepodległości przez Polskę i zatrzymała marsz rewolucji bolszewickiej na Europę Zachodnią. Od niebezpieczeństw zewnętrznych odgradzał Hannę bezpieczny, szczęśliwy, pełen miłości i wrażliwości dom państwa Chrzanowskich.

\section{Młodość w Krakowie}

W tym burzliwym czasie Hanna dorastała w Krakowie i uczyła się prywatnie na pensji, a w latach 1917-1920 była uczennicą w Prywatnym Gimnazjum Realnym Sióstr Urszulanek w Krakowie ${ }^{13}$. Rok 1920 był dla niej czasem matury, ale i wojny. Po maturze, zdanej z wyróżnieniem, przeszła krótki 6-tygodniowy kurs pielęgniarski, prowadzony przez pielęgniarki Amerykańskiego Czerwonego Krzyża ${ }^{14}$, uprawniający do pielęgnowania rannych żołnierzy. Jako wolontariuszka w Klinice Chirurgicznej w Krakowie zetknęła się z ludzkim bólem, cierpieniem i śmiercią. Jej koledzy i ko-

\footnotetext{
${ }^{13}$ Siostry urszulanki osiedliły się przy ul. Starowiślnej w 1875 roku i od początku rozpoczęły działalność dydaktyczno-wychowawczą, prowadząc szkoły na różnym poziomie. W 1909 roku otworzyły liceum, w którym nauka kończyła się egzaminem dojrzałości, ale nie dawał on uprawnień do podejmowania studiów (jedynie w formie wolnych słuchaczek). Dla zapewnienia swym wychowankom dostępu do wyższych uczelni urszulanki zaczęły prowadzić od 1910 roku Realne Gimnazjum Żeńskie, dla którego otrzymały prawa publiczne. Wspomnienia Hanny Chrzanowskiej dotyczą tego okresu nauki u urszulanek.

${ }^{14}$ Przez amerykański Czerwony Krzyż, który przybył do Krakowa, organizowane były w 1918 roku 6-tygodniowe kursy pielęgniarskie. Przeprowadzenie ich było możliwe dzięki m.in. udostępnieniu pomieszczeń przez Stowarzyszenie Pań Miłosierdzia św. Wincentego a Paulo, Towarzystwo Pań Ekonomek oraz Towarzystwo Panien Ekonomek św. Wincentego a Paulo, zrzeszające młode kobiety z kręgu arystokracji, ziemiaństwa i inteligencji - często żony i córki profesorów Uniwersytetu Jagiellońskiego.
} 
leżanki szykowali się do wojny. Była też świadkiem powrotów żołnierzy $\mathrm{z}$ frontów (często wracali mocno okaleczeni). Jako wolontariuszka Hanna bierze też udział w akcji zbierania datków pieniężnych, odzieży i żywności $\mathrm{w}$ domach krakowskich na potrzeby wojny polsko-bolszewickiej.

W latach 1920-1922 studiowała na Wydziale Filozoficznym UJ, studia te przerwała po otwarciu Warszawskiej Szkoły Pielęgniarstwa. Zgłosiła się na kurs dla adeptek pielęgniarstwa, organizowany przez amerykański Czerwony Krzyż. Już wtedy wiedziała, że służba pacjentowi stanie się misją jej życia, dlatego zrezygnowała ze studiów i wstąpiła do Warszawskiej Szkoły Pielęgniarstwa, uzyskując aprobatę obojga rodziców.

\section{Międzywojenne realia}

Tymczasem w Europie i w Polsce doszło do wielu znaczących wydarzeń. We Włoszech zrodził się faszyzm, w sowieckiej Rosji zmarł Lenin, a władzę przejął Józef Stalin. W Niemczech władzę przejęli zwolennicy Hitlera. Aleksander Fleming odkrył pierwszy antybiotyk - penicylinę. W 1929 roku rozpoczął się wielki kryzys ekonomiczny. Polska w tym czasie umocniła swoje granice po wojnie; wybuchły trzy powstania na Śląsku (w latach 1919, 1920 i 1921), trwały spory polityczne, walutą kraju stał się złoty. Janusz Korczak rozpoczął pracę na rzecz ubogich i sierot żydowskich.

\section{Edukacja i praca zawodowa 1922-1939}

Hanna Chrzanowska podjęła pracę w krakowskim ambulatorium Panien Ekonomek Stowarzyszenia Pań Miłosierdzia św. Wincentego a Paulo, które powstało z inicjatywy Marii Epsteinówny ${ }^{15}$, prekursorki polskiego

${ }^{15}$ Maria Epsteinówna (1875-1947), córka bankiera, pionierka szkolnictwa pielęgniarskiego w Polsce. W wieku 20 lat zaczęła działać w Stowarzyszeniu Pań Miłosierdzia św. Wincentego a Paulo, które opiekowało się chorymi i ubogimi. W 1905 roku została prezeską Stowarzyszenia. 5 listopada 1911 roku z jej inicjatywy i przy jej wsparciu utworzono pierwszą na ziemiach polskich szkołę pielęgniarstwa w Krakowie, w której została kierowniczką. Była to tzw. stara szkoła. W grudniu 1925 roku dzięki jej staraniom została otwarta Uniwersytecka Szkoła Pielęgniarek i Higienistek w Krakowie, przy ul. Kopernika 25, w której została dyrektorką. 1 stycznia 1931 roku złożyła rezygna- 
pielęgniarstwa. W tym czasie Hanna poznaje najważniejsze dla siebie osoby, m.in. Marię Epstein. Spełniała się w życiu zawodowym i jemu poświęcała całą siłę i zaangażowanie. Była szczęśliwa, odnalazła miejsce dla siebie. Rodzina Hanny wspierała ją w działaniach, ale ona sama była już na tyle dorosłą osobą, że samodzielnie podejmowała decyzje. Także te, które dotyczyły życia wewnętrznego. Okresowo przebywała w Warszawie, gdzie podjęła pracę w Instytucie Pielęgniarstwa.

Dyplom pielęgniarski Hanna otrzymała w czerwcu 1924 roku. Zdobyła też roczne stypendium Fundacji Rockefellera do Paryża. Tam po raz pierwszy zetknęła się z pielęgniarstwem społecznym (1925-1926). Przyjmując stypendium, musiała zdecydować się po powrocie na pracę instruktorki w nowej szkole w Krakowie, w której dyrektorką była Maria Epsteinówna. W oczekiwaniu na wyjazd, by nie tracić czasu, podjęła studia polonistyczne. Czas spędzony w Paryżu dzieliła między pracę a zwiedzanie olbrzymich galerii Luwru, cotygodniowych koncertach w Starym Konserwatorium.

Zgodnie $\mathrm{z}$ umową stypendialną $\mathrm{w}$ kraju podjęła pracę pedagogiczną w nowo powstałej Uniwersyteckiej Szkole Pielęgniarek i Higienistek w Krakowie przy ul. Kopernika 25, gdzie pracowała na stanowisku instruktorki pielęgniarstwa społecznego i zdrowia publicznego (1926-1929). Uczestniczyła też w kilkumiesięcznym kursie w zakresie higieny szkolnej w Belgii (1928).

W 1928 roku rozpoczęła w szkole wykłady z pielęgniarstwa zdrowia publicznego. Miała w sobie elegancję i klasę, mówiła piękną polszczyzną, ale przede wszystkim stawała się rzeczniczką chorych. Jej wykłady były dowcipne, jasne, mądre, wprowadzające $w$ istotę pracy.

W 1929 roku wyjechała na kilkumiesięczny pobyt do sanatorium w Szwajcarii. Po powrocie do Warszawy wspólnie z przyjaciółką Marią Starowieyską przez 10 lat (1929-1939) redagowała miesięcznik „Pielęgniarka Polska”, pierwsze specjalistyczne czasopismo Polskiego Stowarzyszenia Pielęgniarek Zawodowych. Pisanie fachowych artykułów, łącznie z Kroniką pielęgniarską i przeglądem pism krajowych oraz zagranicznych, zbiegło się z próbami literackimi. W 1934 roku opublikowała pod pseudonimem Agnieszka Osiecka powieść Klucz niebieski, a w 1938 roku Krzyż na pia-

cję ze stanowiska dyrektorki szkoły uniwersyteckiej, aby w wieku 55 lat wstąpić do klauzurowego klasztoru sióstr Dominikanek na Gródku w Krakowie. Ksiądz kard. Franciszek Macharski w kościele sióstr Dominikanek dokonał otwarcia jej procesu beatyfikacyjnego. 
skach. Trzecia z nich: Płonacy śnieg pozostała w maszynopisie. Pisała także wiersze.

W czasopiśmie „Pielęgniarka Polska” opublikowała m.in. swój referat Prace zagraniczne stowarzyszeń pielegniarskich, wygłoszony na X Walnym Zjeździe PSPZ w Krakowie, a także artykuł Szpitale londyńskie. Ponadto ukazały się inne jej artykuły: Z pracy przeciwgruźliczej, O odwiedzinach $w$ rodzinie gruźliczej, Pielegniarka $w$ walce zalkoholizmem, Schronisko Towarzystwa "Ratujmy Niemowlęta" w Warszawie.

Wraz z Teresą Kulczyńską przygotowała praktyczny podręcznik Zabiegi pielegniarskie" (1938, kilkakrotnie wznawiany) oraz brała czynny udział w przygotowaniu, uchwalonej przez Sejm w 1935 roku, Ustawy o pielegniarstwie. Ustawa ta, uznawana za jedną z najlepszych, regulowała zawodowy status pielęgniarek i obowiązywała w Polsce niemal do końca XX wieku. To pierwszy - jak dotąd najlepszy - tego rodzaju dokument na świecie.

W latach 1931-1933 pełniła funkcję asystentki dyrektorki Warszawskiej Szkoły Pielęgniarstwa, którą wówczas kierowała jej ciocia, Zofia Szlenkierówna.

\section{Tragiczne lata okupacji (1939-1945)}

W bombardowanej Warszawie 2 października 1939 roku umiera ciocia Hanny, Zofia Szlenkierówna. Natomiast w ramach akcji Sonderaktion Krakau, 6 listopada 1939 roku aresztowano jej ukochanego ojca, który został wywieziony do obozu Sachsenhausen, gdzie zmarł 19 stycznia 1940 roku. W tym samym roku, na wiosnę, zginął w Katyniu jej jedyny brat Bohdan, absolwent wydziału filozofii UJ, porucznik 20. Pułku Piechoty. Z domu profesorów UJ wraz z matką (zmarła w 1951 roku), bratową i jej maleńką córeczką Wandą, zostały przez władze niemieckie przymusowo eksmitowane i zamieszkały przy ul. Radziwiłłowskiej.

Hanna włączyła się w pracę Sekcji Charytatywnej Obywatelskiego Komitetu Pomocy, utworzonego przez ks. kard. Adama Stefana Sapiehę. Po utworzeniu Rady Głównej Opiekuńczej i wcielenia do niej Sekcji Charytatywnej, wspólnie z Marią Starowieyską objęła kierownictwo Działu Opieki nad Uchodźcami i Wysiedlonymi. Organizowała pomoc dla uchodźców, więźniów, ludzi przesiedlonych, którzy tysiącami napływali do Krakowa. 
Szczególną troską otaczała osierocone dzieci, także żydowskie, poszukując dla nich rodzin zastępczych. Do końca marca 1945 roku pracowała w Sekcji Pomocy Wysiedlonym Polskiego Komitetu Opiekuńczego, jako przewodnicząca działu opieki domowej. Udzielała pomocy wracającym z Rzeszy przymusowym robotnikom i repatriantom.

\section{Powojenne losy}

W reaktywowanej w kwietniu 1945 roku Krakowskiej Szkole Pielęgniarstwa, której dyrektorką była wówczas Anna Rydlówna, Hanna pełniła m.in. funkcję kierownika szkolenia w Otwartej Opiece Zdrowotnej. Na przełomie 1946 i 1947 roku wyjechała na stypendium UNRRA do Stanów Zjednoczonych, by zapoznać się z pielęgniarstwem domowym. Warto zaznaczyć, że jako jedyna jeździła do domów w najbiedniejszych dzielnicach (m.in. Harlemie), gdzie zdobywała nowe doświadczenia. „Tamtejsze pielęgniarki to kwiat pielęgniarstwa amerykańskiego" - wspominała. Po powrocie ze stypendium w USA w pamiętniku Chrzanowska zanotowała, że poza ogólnym pogłębieniem wiedzy, wyniosła stamtąd utwierdzenie, że pielęgniarstwo domowe jest pracą mądrą, bardzo szeroką, że są do jej wykonywania potrzebne bardzo wysokie kwalifikacje. W czasie pobytu w Stanach poznała i zaprzyjaźniła się z Marią Strzembosz ${ }^{16}$, która była jedną ze stypendystek.

Od września 1949 roku Maria Strzembosz rozpoczęła pracę jako instruktorka w Krakowskiej Szkole Pielęgniarstwa. Podjęła równocześnie studia na Uniwersytecie Jagiellońskim, a później warszawskim, które ukończyła w 1954 roku, otrzymując tytuł zawodowy magistra pedagogiki. Pracowała jako nauczycielka pielęgniarstwa.

Hanna Chrzanowska w 1950 roku, na zlecenie ministerstwa zdrowia, przeprowadziła ankietę $\mathrm{w}$ szkołach pielęgniarskich $\mathrm{w}$ sprawie szkolenia z zakresu pielęgniarstwa otwartego, a jej wyniki przekazała w postaci wniosków dotyczących metod kształcenia. Prowadziła także cykl wykładów dla kierowniczek Leczenia Otwartego. Wykładała metodykę pielęgniarstwa

\footnotetext{
${ }^{16}$ Maria Strzembosz - córka Aleksego Dawidowskiego, inżyniera chemika, dyrektora Warszawskiej Fabryki Karabinów na Woli i Janiny z Sagatowskich - siostra Alka Dawidowskiego. Maria Strzembosz była żoną Tomasza Strzembosza i matką Doroty oraz Macieja, producenta.
} 
otwartego w Ośrodku Instruktorek w Warszawie. Swoje doświadczenia starała się przekazywać w wielu publikacjach. Niezależnie od działalności nauczycielskiej i wychowawczej, kontynuowała praktykę.

Dzięki przychylności dyrektorki Anny Rydlówny (później zdegradowanej), w latach 1951-1957 pełniła funkcję wicedyrektorki krakowskiej placówki medycznej, wdrożyła pielęgniarstwo domowe wraz z dwoma tygodniowymi praktykami do programu nauczania. Taką praktykę w szkole pielęgniarstwa domowego pod kierunkiem pani Hanny odbyła Helena Matoga (wicepostulatorka w jej procesie beatyfikacyjnym).

W 1957 roku Hanna Chrzanowska opuściła Szkołę Krakowską i objęła stanowisko dyrektorki Szkoły Pielęgniarstwa Psychiatrycznego w Kobierzynie. Pracowała tam przez rok, gdyż Ministerstwo Zdrowia zlikwidowało placówkę w 1958 roku. Po zamknięciu szkoły przeszła na emeryturę.

\section{Początki pielęgniarstwa parafialnego}

Rok 1956 i 1957 - jak sama pisała w swoim pamiętniku - był okresem przełomu. „Są cierpienia tak ostre, że na szczęście dla człowieka, już się całej ich ostrości nie odczuwa, jak nie słyszy się ultradźwięków. Widzi je, słyszy i ocenia jeden tylko Bóg na szlakach swej własnej dla nas niedostępnej, absolutnej sprawiedliwości”'17.

$\mathrm{Na}$ emeryturze nie zaprzestała swej działalności, zaangażowała się w pomoc przewlekle chorym. Umieszczała osoby samotne i niechciane przez rodziny w domach spokojnej starości. Szybko i skutecznie organizowała pomoc domową, zapewniając lepsze warunki ekonomiczne. Do końca życia organizowała i prowadziła fachową pomoc terminalnie chorym, zaczęła myśleć, by opiekę nad chorymi oprzeć na Kościele. W czerwcu 1957 roku razem z Zofią Szlendak, która była instruktorką pielęgniarstwa domowego w szkole krakowskiej, poszły do ks. Karola Wojtyły, który wraz ks. infułatem Machayem nie odmówił im pomocy.

W roku 1971 Hanna zapoczątkowała organizowanie wczaso-rekolekcji dla chorych. Do współpracy zaprosiła siostry zakonne (szarytki odmówiły, ale współpracę podjęły siostry józefitki za namową ks. abpa Baziaka), organizowała dwutygodniowe turnusy wczaso-rekolekcji dla chorych, turnu-

${ }^{17}$ H. Chrzanowska, Pamiętnik..., s. 137. 
sy wyjazdowe do Trzebini, Kalwarii Zebrzydowskiej. Do obsługi turnusów zgłaszali się studenci, przez nią skłaniani do współpracy, którzy nie oblewali egzaminów, oraz klerycy i ochotnicy.

Hanna Chrzanowska była przewodniczką po świecie ludzkiego cierpienia. Prowadziła ks. kard. Karola Wojtyłę do obłożnie chorych, wskazywała, jak można i należy im pomóc, podjęła prekursorskie dzieło pielęgniarstwa parafialnego. Opiekę nad chorymi w domu opierała na pielęgniarstwie parafialnym. Zależało jej na tym, by pielęgnowanie chorego w domu nie było traktowane jako coś sporadycznego czy przypadkowego, ale jako pełne zobowiązanie. W tym dziele wspierali ją i decydującą rolę odegrali ks. abp Karol Wojtyła i archiprezbiter bazyliki mariackiej ks. infułat Ferdynand Machay.

Była bardzo odważna, o mocnym charakterze, bezpośrednim sposobie bycia, bezinteresowna i rozumnie tolerancyjna. W 1966 roku zaczęła poważnie chorować. Przeszła operację chirurgiczną usunięcia guza, a następnie kolejne sesje radioterapii, ale choroba postępowała. Otrzymała od Ojca Świętego Pawła VI order Pro Ecclesia et Pontifice (1971), a od władz Krzyż Kawalerski Orderu Odrodzenia Polski. Pracowała nieustannie, niezależnie od postępującej choroby. Jeszcze w lutym 1973 roku wygłosiła swój ostatni referat Apostolstwo świeckich w opiece nad chorymi. Umocniona sakramentem chorych, umarła 29 kwietnia 1973 roku.

\section{Zasady pielęgniarstwa parafialnego}

Dział pielęgniarstwa parafialnego według programu Hanny Chrzanowskiej obejmował opiekę długoterminową, hospicjum domowe, opiekę terminalną. Swoje praktykantki i przyszłe adeptki zawodu „wtajemniczała”.

- Lekcja pierwsza: dobra pielęgniarka tym więcej może, im więcej umie. Ma wielu chorych, musi więc zachować porządek. Po wizycie robimy krótką notatkę, do której sięgamy przed następnymi odwiedzinami. Uwaga: Nigdy nie notujemy w obecności chorego i jego rodziny.

- Lekcja druga: połączona z wizytą u chorego. Otwiera się na potrzeby zarówno materialne, jak i duchowe. Dzięki niej upowszechnił się zwyczaj odprawiania Mszy św. w domu chorego.

- Lekcja trzecia. Posługiwanie z niezwykłą sumiennością, organizacyjną perfekcją i bezgraniczne poświęcenie. 
Hanna Chrzanowska łączyła w sobie perfekcyjność w zawodzie i cechy społecznikowskie. Była wzorem godnym naśladowania. Ironia losu, że w okresie buntu nie znosiła rekolekcji, a potem - od 1955 roku - sama organizowała je dla pielęgniarek w kościele na Gródku. Napisała Rachunek sumienia pielegniarki. Prawdopodobnie to kontakt $\mathrm{z}$ Marią Starowieyską spowodował duchowy przełom u Hanny, która z osoby odległej od Boga stała się wierzącą katoliczką. Wraz z przyjaciółką Teresą Kulczyńską konsultowała program pierwszej polskiej uczelni powstałej przy Akademii Medycznej w Lublinie.

\section{Przejrzyste świadectwo życia}

Ksiądz kard. Franciszek Macharski tak mówił o Hannie Chrzanowskiej: „Była sumieniem środowiska pielęgniarskiego”, a ks. kard. Stanisław Dziwisz nazwał ją Matką Teresą Krakowa. Natomiast Zofia Konderska i dr Rachela Hutner, współpracownice Hanny Chrzanowskiej, tak o niej napisały: „Posiadała niezwykłą osobowość, urzekała swym optymizmem, budziła podziw swym poczuciem odpowiedzialności za wyrażaną postawę oraz podejmowane działania. Podziwiana była za prostotę, wewnętrzny ład, potrzebę czynienia dobra. Te właśnie cechy predestynowały ją do działalności społecznej. Wykładnikiem tej postawy był wybór zawodu pielegniarskiego, który najbardziej wyrażał się w jej stosunku do ludzi potrzebujących pomocy i zrozumienia". Potrzebę pracy społecznej potwierdziła swym udziałem w organizowaniu Polskiego Towarzystwa Pielęgniarskiego w Krakowie, a następnie uczestnictwem w Zarządzie Głównym tego stowarzyszenia, wnosząc doświadczenia sięgające lat przedwojennych. W ciągu długiego okresu pracy w charakterze instruktorki w szkołach pielęgniarstwa prowadziła wykłady, posługując się językiem prostym, logicznym, wskazując na najważniejsze problemy. Prowadząc zajęcia praktyczne, stanowiła wyzwanie dla słuchaczek, stawiając dla nich wzór najbardziej godny naśladowania.

Potrafiła się wznieść ponad osobiste odczucia i stawiać na pierwszym planie dobro pielęgniarstwa. Nie wahała się współpracować z osobą o odmiennych poglądach w wydawanym w 1956 roku podręczniku dla pielęgniarek przy bardzo ważnym rozdziale: Pielegniarstwo w otwartej opiece zdrowotnej. Jak wspominały jej współpracownice, była to „osoba łatwa 
w kontaktach, życzliwa, z dużym poczuciem humoru. Przebywanie z nią było przyjemne, interesujące i pobudzające”18. „Pani Hanna była osobą, która nigdy nie podnosiła głosu, jak mało kto potrafiła przyciągać wartościowych ludzi do współpracy. Miała subtelną umiejętność współpracy z ludźmi, dzięki czemu jej inicjatywa stawała się dziełem wspólnym”" ${ }^{19}$. Była człowiekiem miłosierdzia, ale nie pobłażliwym. Cechowały ją: wspaniałość ducha, bogactwo wiedzy i przykład wzorowej pielęgniarki. Na pierwszym miejscu widziała człowieka, jego godność, a potem dopiero chorobę. Jej działalność to wyznanie wiary: Credo. W 1956 roku na ręce swojego spowiednika o. Piotra Rostworowskiego w Tyńcu złożyła przyrzecznie oblackie i przyjęła imię Klara.

Ksiądz kard. Karol Wojtyła powiedział na jej pogrzebie 2 maja 1973 roku: „Dziękujemy Ci, Pani Hanno, za to, że byłaś wśród nas; że byłaś taka, jaka byłaś. Dziękują Ci za to opiekunki chorych, siostry zakonne, pielęgniarki, młodzież akademicka - cały Kościół krakowski. Dziękuję Ci za to jako biskup Kościoła krakowskiego. Byłaś dla mnie ogromną pomocą i oparciem. A raczej dziękujemy Bogu za to, że byłaś wśród nas taka, jaka byłaś - z tą Twoją wielką prostotą, z tym wewnętrznym spokojem, a zarazem $\mathrm{z}$ tym wewnętrznym żarem; że byłaś wśród nas jakimś wcieleniem Chrystusowych błogosławieństw z Kazania na Górze; zwłaszcza tego, kiedy mówił: Błogosławieni miłosierni. Dziękujemy Panu Bogu za to życie, które miało taką wymowę, które pozostawiło nam takie świadectwo; tak bardzo przejrzyste, tak bardzo czytelne...”. Te słowa są najpiękniejszym podsumowaniem życia bł. Hanny Chrzanowskiej.

${ }^{19}$ Wypowiedź pani Heleny Matogi, która pracowała z Hanną Chrzanowską. 


\section{Bibliografia}

Chrzanowska H., Pamiętniki, listy, notatki, oprac. A. Rumun, M. Florkowska, Kraków 2018.

Chrzanowska H., Rachunek sumienia dla pielegniarki, w: Wirtualny magazyn pielegniarki i położnej; nursing.com.pl 2011-10-09 (dostęp: 14.07.2017).

Ćwiertnia I., Idea pielegniarstwa rodzinnego w działalności Hanny Chrzanowskiej, „Ad Vocem”, Pismo Małopolskiej Okręgowej Izby Pielęgniarek i Położnych w Krakowie; www.moipip.org.pl, 2011 (dostęp: 14.04.2017).

Radość dawania. Hanna Chrzanowska we wspomnieniach, listach, anegdotach, oprac. M. Florkowska, Kraków 2009.

Zuchniewicz P., Siostra naszego Boga. Niezwykła historia Hanny Chrzanowskiej, Kraków 2017. 